\title{
Separation of Four Impurities and Degradants By HPLC: A Case of Bicalutamide
}

\author{
Ashu Mittal ${ }^{1}$ \\ Orcid :0000-0003-3284-0445, \\ Alankar Shrivastava ${ }^{2 *}$ \\ Orcid: 0000-0002-2498-9875
}

${ }^{1}$ KIET Group of institutions (KIET school of pharmacy), Ghaziabad, India

${ }^{2}$ KIET Group of institutions (KIET school of pharmacy), Ghaziabad, India

Corresponding author:

Alankar Shrivastava

KIET Group of institutions (KIET school of pharmacy), Ghaziabad, India

E mail: alankar.shrivastava@kiet.edu

\begin{abstract}
Bicalutamide is an antiandrogen preparation primarily indicated for the treatment of treat prostate carcinoma. Although several analytical methods have been described, a liquid chromatography method determination in the presence of impurities (Impurity A, B, C and BIC-2) and degradation products is still unexamined. Thus, a simple chromatography method is illustrated for bicalutamide in the presence of impurities and degradation products under stress conditions.

The separation method is reverse phase, with octyl column on Agilent HPLC 1100 series equipment. The mobile phase was combination of phosphate buffer and acetonitrile. The developed method was validated according to International Conference on Harmonisation Guidelines. Bicalutamide and its four process related impurities and degradants were successfully separated by using proposed method. The method was found to be linear between 70 to $130 \mu \mathrm{g} / \mathrm{ml}$, the regression equation $\mathrm{y}=19.647 \mathrm{x}+18.645$ with correlation coefficient value of 0.9999 . The method was found to be accurate and precise enough to be used for analysis. The LOD and LOQ values found were $0.031,0.031,0.031,0.028,0.029 \mu \mathrm{g} / \mathrm{ml}$ and $0.083,0.083,0.103,0.075,0.098 \mu \mathrm{g} /$ $\mathrm{ml}$ for impurity A, B, C, BIC-2 and BCL respectively.

The proposed analytical methodology is simple, robust, specific and accurate enough for routine analysis of bicalutamide API and its other four process related impurities and degradants.
\end{abstract}

Keywords: Analytical methods, Bicalutamide, bicalutamide impurities, method development, analysis 


\section{Introduction}

Prostate cancer is one of the leading cause of deaths worldwide among men and is next most common cancer after lung cancer $[1,2]$. In the progression and development of prostate cancer, androgen receptors (AR) plays prominent role [3-5]. Bicalutamide is an analogue of active metabolite of flutamide, a potent nonsteroidal AR antagonist, slowly absorbed after administering through oral route with 1 week lengthy elimination half-life [6].

Bicalutamide (CAS: 90357-06-5, mol formula: $\mathrm{C}_{18} \mathrm{H}_{14} \mathrm{~F}_{4} \mathrm{~N}_{2} \mathrm{O}_{4} \mathrm{~S}$, mol wt: $430.4 \mathrm{~g} / \mathrm{mol}$, fine white to off-white, Fig. 1) was introduced for clinical trial in 1989 with the brand name Casodex and FDA approved for its use in 1995 [7]. It has a relatively long half-life of approximately a week and is extensively metabolized in the liver [8]. The active component is $R$-enantiomer and preferentially indicated in Prostate carcinoma [9]. The dose ranging studies (phase 2 and 3) confirms $150 \mathrm{mg} / \mathrm{d}$ dosage as appropriate to be used as monotherapy [10].

The available literature shows various analytical methods available for the determination of BCL in different matrices. The methods found are UV Spectrophotometry [11-13], HPLC methods [14-29], HPTLC [30] and Electroanalytical method [31] by using Cyclic Voltammetry and Differential Pulse Voltammetry.

Spectrophotometry is known for routine application in analytical field and relatively inexpensive technique with some limitations such as lesser selectivity and sensitivity [32]. The disadvantage of HPLCMS method is the cost of analysis. These systems are costly and servicing is also added to the expense. HPLC is used for analysis since it requires the least amount of sample, the test can vary according to the quantitative amount required, and the results are reliable [33]. This our intension of method development is simple, cost effective and sensitive method for separation of bicalutamide and its impurities. Forced degradation studies were performed proving method is specific. The validation of method is done as per ICH guidelines

\section{Metarial and Methods}

The HPLC instrument used was Agilent 1100 series, equipped with Zorbax Eclipse XDB C8 (4.6 × 250 $\mathrm{mm} ; 5 \mu \mathrm{m})$ column. The chemicals were purchased from Merck and Bicalutamide and impurities were received as gift samples from Sun Pharmaceuticals.
(2)<smiles>CC(O)(CS(=O)(=O)c1ccccc1)C(=O)Nc1ccc(C#N)c(C(F)(F)F)c1</smiles>

(3)<smiles>CC(O)(CS(=O)(=O)c1cccc(F)c1)C(=O)Nc1ccc(C#N)c(C(F)(F)F)c1</smiles>

(5)<smiles>CC1(C(=O)Nc2cccc(C(F)(F)F)c2C#N)CO1</smiles>

Figure 1. Chemical structures: (1) Bicalutamide (BCL), (2) Impurity A, (3) Impurity B, (4) Impurity C, (5) BIC-2 


\section{Optimization of chromatographic conditions}

The lipophilicity of bicalutamide is high $(\log P ; 2.92)$ and the poor solubility in water $(5 \mathrm{mg} / \mathrm{L})$. Thus, mixture of acetonitrile and water was initially tried for development of study. It was found that using buffer solution, the peak of drug observed was most suitable and thus used in further validation procedures.

\section{Chromatographic conditions}

The separation was accomplished on a Zorbax Eclipse XDB $\mathrm{C}_{8}(4.6 \times 250 \mathrm{~mm} ; 5 \mu \mathrm{m})$ column under isocratic mode for separation of BCL API from impurities. The mobile phase was $0.01 \mathrm{M} \mathrm{KH}_{2} \mathrm{PO}_{4}$ (pH 3.0): acetonitrile (55:45) and a PDA detector set at $272 \mathrm{~nm}$ were used for assay determination and gradient profile for impurities determination. Flow rate kept was $1.5 \mathrm{ml} / \mathrm{min}$, injector volume $10 \mu \mathrm{l}$ and run time was $15 \mathrm{~min}$. The separation was performed under ambient temperature. The 1:1 ratio of water and acetonitrile was used as diluent.

\section{Preparation of buffer}

The dilution of potassium dihydrogen orthophosphate $(1 \mathrm{~L})$ was prepared by dissolving $1.36 \mathrm{~g}$ and adjusting $\mathrm{pH}$ to $3 \pm 0.05$ with dilute ortho phosphoric acid solution and filtered using $0.45 \mu$ filter.

\section{Preparation of stock solution}

Accurately weighed and transferred about $25 \mathrm{mg}$ of sample to a $25 \mathrm{ml}$ volumetric flask, $15 \mathrm{ml}$ diluent was added, sonicated to dissolve, diluted to volume with diluent and blended properly. Dilute $5 \mathrm{ml}$ of this solution to $50 \mathrm{ml}$ with diluent and blended properly.

\section{Preparation of sample solution}

Accurately weighed and transferred about $25 \mathrm{mg}$ of sample to a $25 \mathrm{ml}$ volumetric flask, $15 \mathrm{ml}$ of diluent was added, sonicated and diluted to volume with diluent and blended properly.

\section{Evaluation of system suitability}

The prepared standard solution five times and number of theoretical plates, USP tailing factor and standard deviation of area counts were observed. The number of theoretical plates found to be more than 8000 , the tailing factor and standard deviation of area counts was found to be less than 1.5 and $1 \%$ respectively. The method was found to be suitable for further study.

\section{Results and Discussions}

\subsection{Validation}

\section{Selectivity}

The impurities (listed below) were spiked with sample solution to examine the interference, if any, with Bicalutamide.

Impurity A: N-(4-Cyano-3-trifluoromethylphenyl)3-(4-fluorophenylthio)-2-hyrdoxy-2-methyl propi-

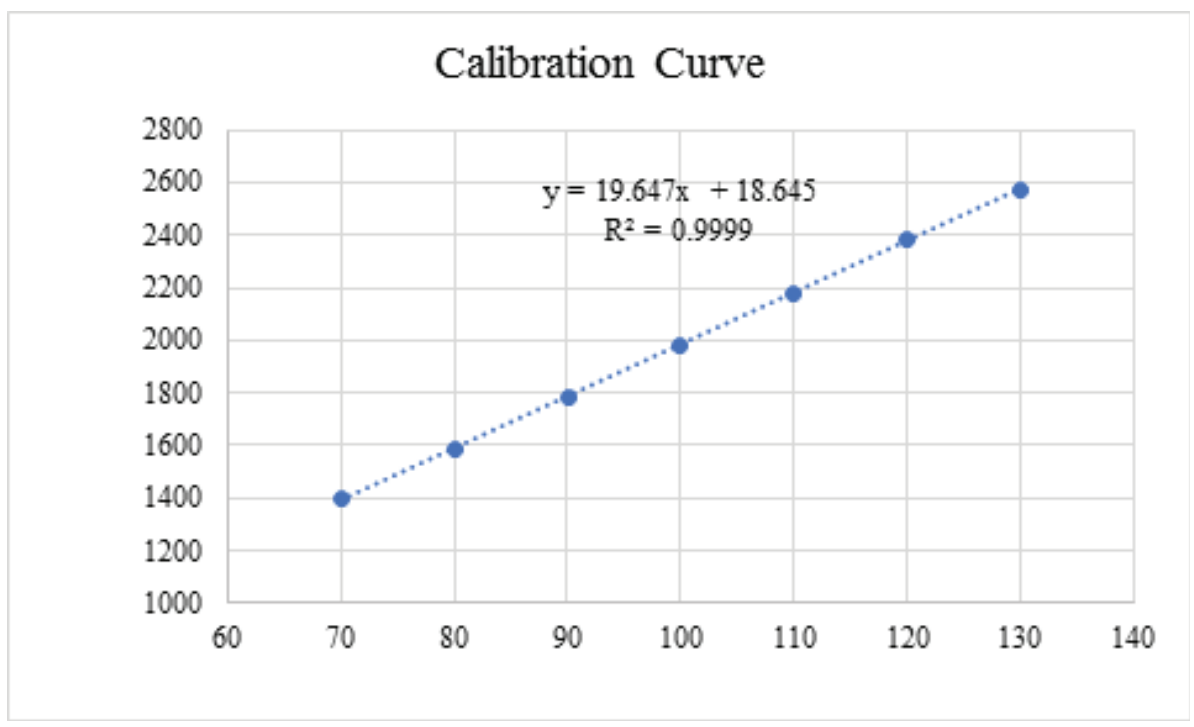

Figure 2. Calibration curve 
Table 1. Data for selectivity

\begin{tabular}{ccc}
\hline Sample & Purity factor of Bicalutamide peak & Purity Threshold \\
\hline Standard solution & 999.837 & 980 \\
Control sample solution & 999.795 & 980 \\
Spiked sample solution & 999.100 & 980 \\
\hline
\end{tabular}

Table 2. Data of Retention times

\begin{tabular}{ccc}
\hline S No & Peaks & Retention Time (min) \\
\hline 1 & Impurity B & 3.7 \\
2 & BIC-2 & 4.8 \\
3 & Impurity C & 5.5 \\
4 & Bicalutamide & 5.7 \\
\hline 5 & Impurity A & 13 \\
\hline
\end{tabular}

onamide

Impurity B: N-(4-Cyano-3-trifluoromethylphenyl)3-(4-fluorobenzenesulphinyl)-2-hydroxy-2-methyl propionamide

Impurity C: N-(4-Cyano-3-trifluoromethylphenyl)3-(2-fluorobenzenesulfonyl)-2-hydroxy-2 methyl propionamide

BIC-2: 2-Methyloxirane-2-carboxylic acid-(4-cyano-3-trifluoromethyl phenyl) amide

The impurities were found to be well separated from each other in the given conditions. The peak purity factor for Bicalutamide in standard, sample and spiked sample of Bicalutamide indicates that peak was pure and has no interferences. The purity factor found was more than purity threshold. The data found in selectivity and retentions times are given in Table 1 and 2 respectively. Chromatograms shown in Figure 3.

\section{Forced degradation study}

\section{Alkaline stress conditions}

BCL was treated with 2N Sodium Hydroxide solution as per methodology and analysed until 24 hours by the method for the degradation products. The deg- radation in base stress sample with respect to control was found to be $39.9 \%$ at the end of 24 hours.

\section{Acid stress study}

BCL sample was treated with 5N Hydrochloric acid solution. The solution of this acid treated sample was prepared and analysed until 24 hours by the method for the degradation products. No degradation was observed.

\section{Oxidative stress study}

Drug sample was treated with $5 \mathrm{ml}$ of $30 \% \mathrm{w} / \mathrm{v} \mathrm{H}_{2} \mathrm{O}_{2}$ solution. Solution of this peroxide treated sample was prepared and analysed until 24 hours by the method for the degradation products. No degradation was observed.

\section{Heat stress study}

Thermal degradation was performed at $105{ }^{\circ} \mathrm{C}$ for 10 days. Sample was prepared and analysed by the method for the degradation products. No degradation was observed.

\section{Light stress study}

BCL was carried out by allowing exposure of sample under fluorescent light ( $5 \mathrm{Klux} / \mathrm{h}$ ) and Xenon light (1.3 Wh/m2) for 10 days in a photolytic chamber. 


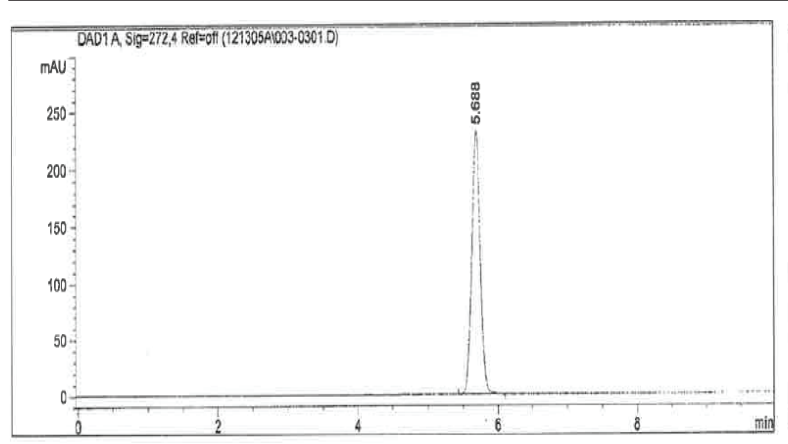

(1) RT: 5.688

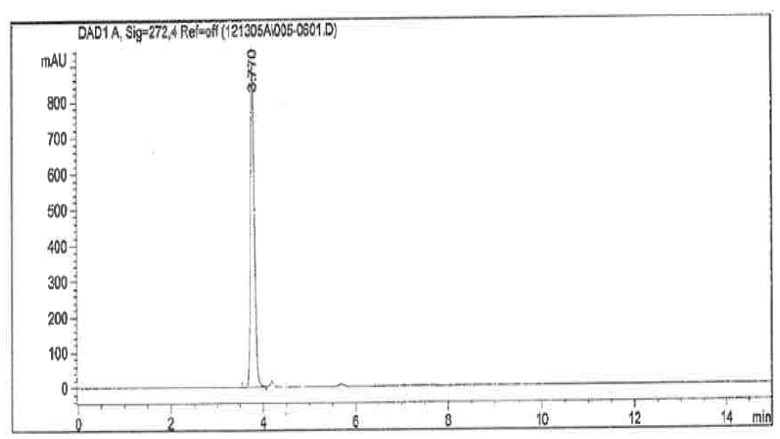

(3) RT: 3.770

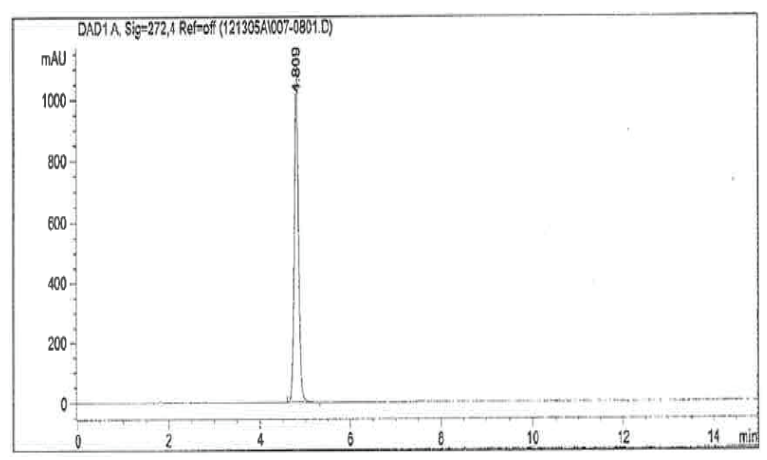

(5) RT: 4.809

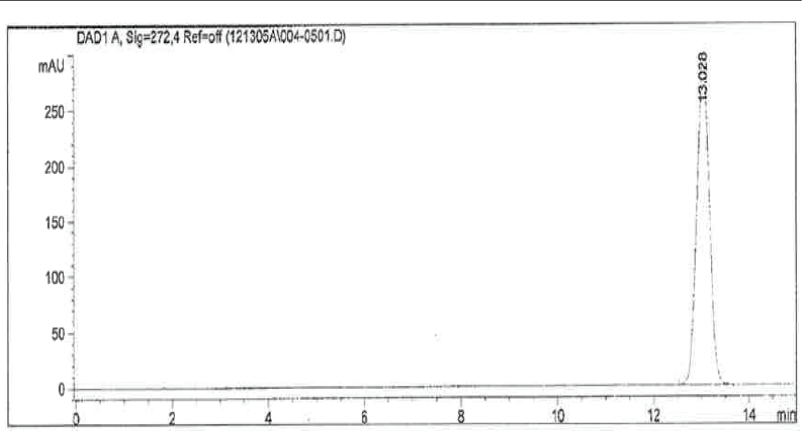

(2) RT: 13.028

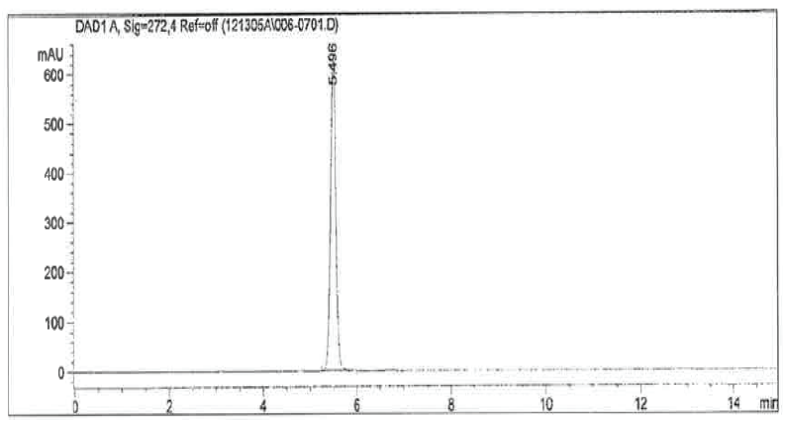

(4) RT: 5.496

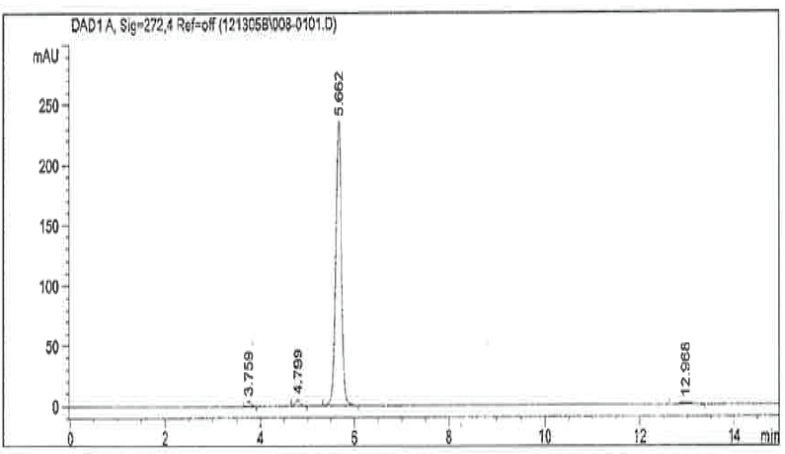

(6) RT: 3.759, 4.769, 5.662, 12.968

Figure 3. Representative chromatograms of selectivity (1) Sample, (2) Impurity A, (3) Impurity B, (4) Impurity C, (5) BIC-2, and (6) Spiked sample

Table 3. Summary of degradation studies

\begin{tabular}{|c|c|c|c|c|c|}
\hline Mode of degradation & Condition & $\begin{array}{c}\text { Assay }(\% \\
\text { w/w) }\end{array}$ & $\begin{array}{l}\text { \% Degradation w.r.t. } \\
\text { control }\end{array}$ & Purity factor & $\begin{array}{l}\text { Purity } \\
\text { threshold }\end{array}$ \\
\hline Control & No treatment & 98.7 & - & 999.795 & 980 \\
\hline Base stress study & $2 \mathrm{~N} \mathrm{NaOH}$ for $24 \mathrm{hrs}$ & 59.3 & 39.9 & 999.875 & 980 \\
\hline Acid stress study & $5 \mathrm{~N} \mathrm{HCl}$ for $24 \mathrm{hrs}$ & 98.9 & No degradation & 999.830 & 980 \\
\hline Peroxide stress study & $5 \mathrm{ml}$ of $30 \% \mathrm{H}_{2} \mathrm{O}_{2}$ for $24 \mathrm{hrs}$ & 99.4 & No degradation & 999.846 & 980 \\
\hline Heat stress study & 10 days at $105^{\circ} \mathrm{C}$ & 99.2 & No degradation & 999.755 & 980 \\
\hline Light stress study & $\begin{array}{c}\text { Fluorescent light }(5 \mathrm{Klux} / \mathrm{h}) \\
\text { and Xenon light }(1.3 \mathrm{Wh} / \\
\mathrm{m} 2) \text { for } 10 \text { days }\end{array}$ & 98.2 & No degradation & 999.789 & 980 \\
\hline
\end{tabular}




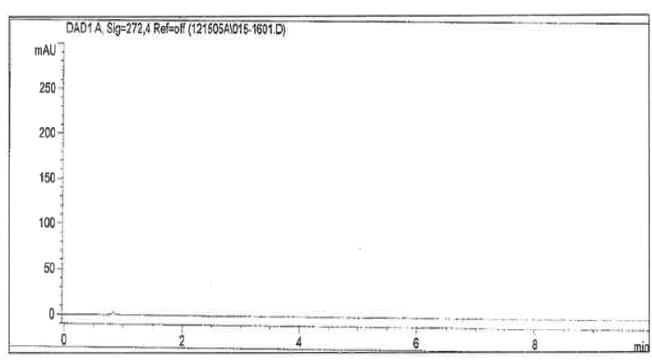

(1)

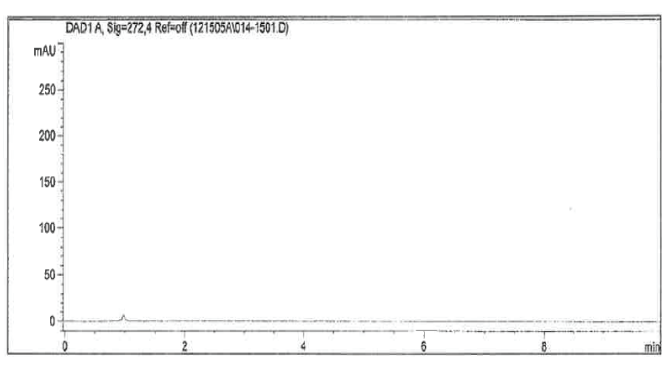

(3)

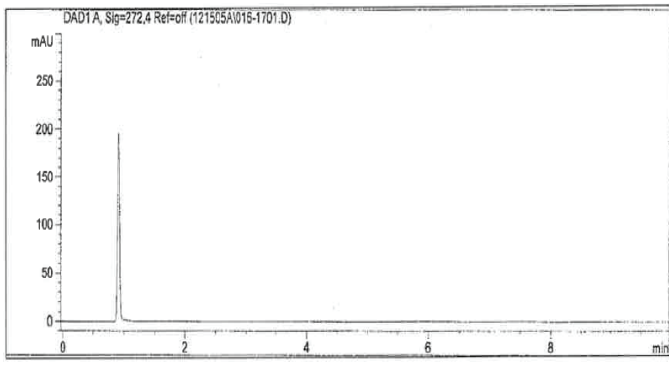

(5)

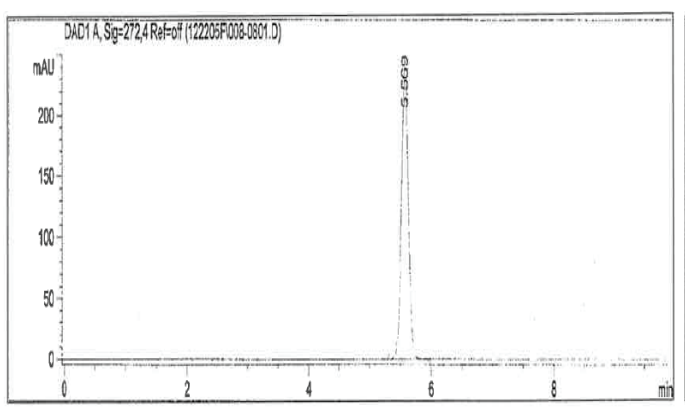

(7)

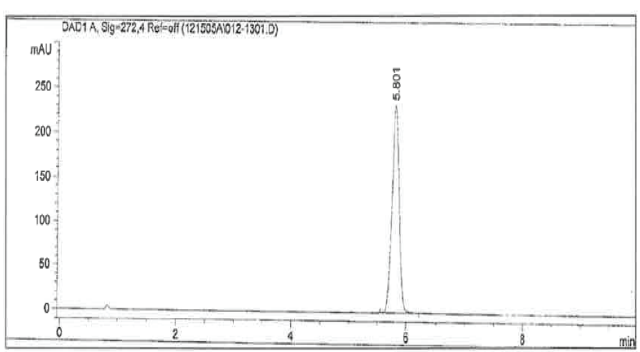

(2)

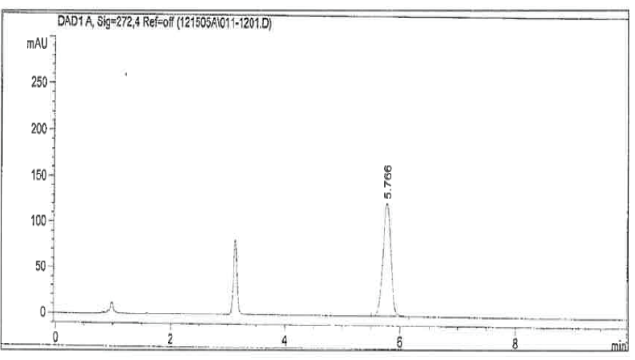

(4)

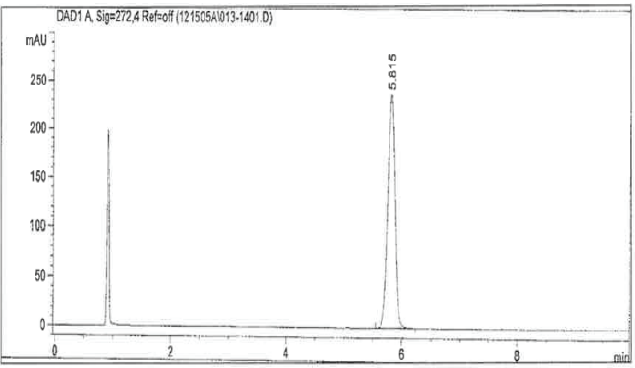

(6)

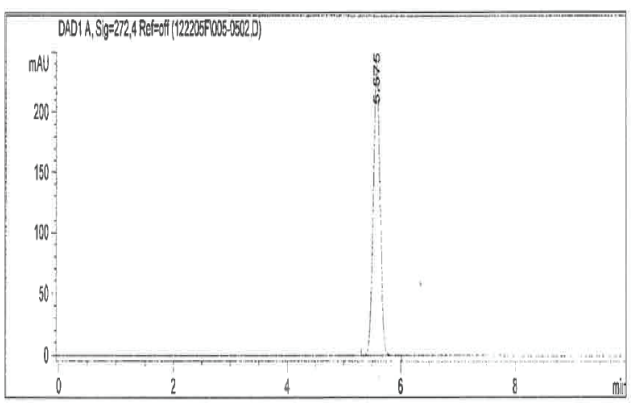

(8)

Figure 4. Representative chromatogram of, (1) Blank, acidic hydrolysis, (2) Sample, acid hydrolysis, (3) Blank, alkaline hydrolysis, (4) Sample, alkaline hydrolysis, (5) Blank, peroxide oxidation, (6) Sample, peroxide hydrolysis, (7) Sample, heat degradation, (8) Sample, photo degradation

Sample was prepared and analysed by the method for degradation products. No degradation was observed. Under peak purity test, the purity of BCL was checked at each stage. The result obtained after observing peak purity the peaks were homogeneous and nonexistence of co-eluting peaks confirms meth- od specific and stability indicating. Results given under Table 3, also refer Figure 4.

\section{Linearity}

The linearity assessed in the specific range i.e. 70 to $130 \mu \mathrm{g} / \mathrm{ml}$ (Figure 2). The results are present in the 
Table 4. Method Precision of proposed method $(n=9)$

\begin{tabular}{|c|c|c|c|c|c|}
\hline S No & Level & $\begin{array}{c}\text { Assay } \\
(\% \text { w/w) }\end{array}$ & Mean & SD & $\%$ RSD* \\
\hline 1 & $80 \%$ & $\begin{array}{l}100.8 \\
100.0 \\
101.8\end{array}$ & 100.9 & 0.94 & 0.93 \\
\hline 2 & $100 \%$ & $\begin{array}{l}100.7 \\
101.1 \\
100.9\end{array}$ & 100.9 & 0.17 & 0.17 \\
\hline 3 & $120 \%$ & $\begin{array}{l}101.2 \\
100.4 \\
100.4\end{array}$ & 100.7 & 0.46 & 0.45 \\
\hline
\end{tabular}

* Statistical Evaluation: The \%RSD at all levels is within limit

table and represented graphically indicating that the response for the BCL peak was linear over the range of $80-100 \%$ of the target concentration $(n=3)$.

\section{Precision}

Precision of the analytical method was demonstrated by system precision, method precision and intermediate precision.

\section{System precision}

Five repeated injections of standard solution were given in to the HPLC. The RSD found to be $0.7 \%$ indicating results are within acceptable precision.

\section{Method precision}

Sample solution was prepared in triplicate at three levels i.e. $80 \%, 100 \%$ and $120 \%$ of the specification level and analysed as per analytical methodology. The assay values, their mean, standard deviation and RSD were calculated. The RSD for the 9 preparations of sample solution was found to be $0.5 \%$.

\section{Intermediate precision}

Determined by analyzing a single batch of sample by different analysts working on different instruments on different days equipped with different columns. The overall RSD found to be $0.7 \%$ indicates the results are within the acceptable precision.

\section{Accuracy}

Sample solution was prepared in triplicate at three levels i.e. $80 \%, 100 \%$ and $120 \%$ of the specification level and analysed as per analytical methodology. Accuracy of the method as inferred from the method precision was found to be in the range of $100-101.8 \%$.

\section{Range}

From the linearity, precision and accuracy experiment, the range of the analytical method was inferred to be between $80-120 \%$ of the sample concentration.

\section{Stability in analytical solution}

The sample solution was prepared and analysed initially and at various time intervals stored at room temperature as per analytical methodology. The cumulative RSD for area counts of BCL peak, up to $1428 \mathrm{~min}$ is within the acceptance criteria, indicating that the sample solution is stable for 24 hours.

The sample solution was prepared and analysed initially and at various time intervals stored at $5{ }^{\circ} \mathrm{C}$ temperature. the cumulative RSD for area counts of Bicalutamide peak, up to $1369 \mathrm{~min}$ is within the acceptance criteria, indicating that the sample solution is stable for 22 hours.

Based on the data obtained, it is recommended to perform all routine analysis and store all solutions at room temperature.

\section{Robustness}

Robustness of the method was determined by deliberately varying the instrumental conditions such as variations in mobile phase composition $( \pm 2 \%)$, flow rate of mobile phase $( \pm 10 \%)$, $\mathrm{pH}$ of the buffer $( \pm 0.2)$ and column oven temperature $\left( \pm 2{ }^{\circ} \mathrm{C}\right), n=3$. The system suitability conditions were met at each variable condition showing the method is robust. In each condition, number of theoretical plates found was above 8000 , USP tailing 1.0 and \%RSD not more than 2 at any case. 
Table 5. Intermediate Precision data

\begin{tabular}{ccc}
\hline & \multicolumn{2}{c}{ Assay of Bicalitamide (\%w/w) } \\
\hline Mean & Analyst 1: 100.8 & Analyst 2: 99.8 \\
SD & 0.54 & 0.28 \\
RSD (\%) & 0.5 & 0.3 \\
Overall Mean & & 100.3 \\
Overall SD & 0.67 \\
* Overall RSD (\%) & 0.7 \\
\hline
\end{tabular}

*Statistical Evaluation: The \%RSD is less than 1\% shows within acceptable limit

\section{Limit of Detection and Quantitation}

The determination of Limit of Detection and Quantitation of impurities A, B, C, BIC 2 and BCL was based performed on the technique of signal to noise ratio.

Solution having different concentrations of individual impurities and of BCL were prepared, six replicate injections of blank and solutions were given and results for the determination of the Limit of Detection (LOD) and Limit of Quantitation (LOQ).

\section{Deviations}

Under the selectivity study, acceptance criteria state that there should not be any interference from the impurities at the retention time of Bicalutamide peak. However, the impurity $\mathrm{C}$ peak was found to be merging with Bicalutamide peak. Justification: Impurity $\mathrm{C}$ is a process impurity (positional isomer) and not a degradation product. Peak purity of the spiked sample is greater than the purity threshold. The assay of sample spiked with impurity at $1 \%$ level was done in triplicate. There is not much difference in the assay values compared with the unspiked samples.

\subsection{Discussion}

Hormone receptors play a prominent role in the development of many malignancies [34]. Bicalutamide is first generation nonsteroidal antiandrogen (NSAA) obstructs androgens effect on cell of prostate [35]. The analytical methods are important part of drug development process. Already discussed that various different analytical methods are being developed for bicalutamide for different purpose using different methodologies. The separation of potential degradants and impurities are required before drug approval process. The presented study is based on simple liquid chromatography method suitable for proper separation of degradants and four other process related impurities. The method was properly developed and validated following ICH guidelines. The $r^{2}$ value of proposed method is very near to 1 , which shows linearity. The other validation parameters e.g. values of accuracy and precision were also found to be sufficient, with in the criteria of established guidelines. The method also found to be robust and stable enough for control of quality.

\section{Conclusion}

The analytical method for detection and separation of four impurities and degradation products by RPHPLC method developed and validated confirming ICH guidelines. All validation parameters described in the guidelines were established i.e. specificity, linearity, range, accuracy, precision, system suitability and stability. The developed method found to be fast, precise and sufficient trueness of results for quantification of bicalutamide in the presence of impurities and degradation products. The method was properly validated according to guidelines and non-existence of interference peaks at the retention times confirms suitability of developed method. The developed analytical methodology can be used for simultaneous detection and quantification of drug and its components within the scope of this study in formulations and can be extended for in vitro and in vivo studies with suitable modification for pharmacokinetic and pharmacodynamic studies. 
Hacettepe University Journal of the Faculty of Pharmacy

Table 6. Data of robustness

\begin{tabular}{|c|c|c|c|}
\hline Conditions & No. of theoretical plates & USP tailing & $\%$ RSD \\
\hline Variation in mobile phase composition (53:47) & 10210 & 1.0 & 0.2 \\
\hline Variation in mobile phase composition (57:43) & 10972 & 1.0 & 0.04 \\
\hline Variations in mobile phase flow $(1.35 \mathrm{ml} / \mathrm{min})$ & 11256 & 1.0 & 0.2 \\
\hline Variations in mobile phase flow $(1.65 \mathrm{ml} / \mathrm{min})$ & 9855 & 1.0 & 0.2 \\
\hline Variation in $\mathrm{pH}$ of buffer ( $\mathrm{pH} 2.8)$ & 10584 & 1.0 & 0.2 \\
\hline Variations in $\mathrm{pH}$ of buffer ( $\mathrm{pH} 3.2$ ) & 10498 & 1.0 & 0.2 \\
\hline Variations in wavelength $(270 \mathrm{~nm})$ & 10536 & 1.0 & 0.2 \\
\hline Variations in wavelength $(274 \mathrm{~nm})$ & 10537 & 1.0 & 0.2 \\
\hline Variations in column oven temperature $\left(23^{\circ} \mathrm{C}\right)$ & 10572 & 1.0 & 0.1 \\
\hline Variations in column oven temperature $\left(27^{\circ} \mathrm{C}\right)$ & 10842 & 1.0 & 0.1 \\
\hline Limit & NLT 8000 & NMT 1.5 & NMT $2.0 \%$ \\
\hline
\end{tabular}

Table 7. Limit of Detection and Quantitation

\begin{tabular}{cccccc}
\hline S No & $\begin{array}{c}\text { Name of } \\
\text { compound }\end{array}$ & S/N ratio & Limit of detection $(\boldsymbol{\mu g} / \mathbf{m l})$ & S/N ratio & $\begin{array}{c}\text { Limit of } \\
\text { Quantitation }(\boldsymbol{\mu g} / \mathbf{m l})\end{array}$ \\
\hline 1 & Impurity A & 4.046 & 0.031 & 9.95 & 0.083 \\
2 & Impurity B & 4.155 & 0.031 & 10.98 & 0.083 \\
3 & Impurity C & 2.97 & 0.031 & 8.94 & 0.103 \\
4 & BIC 2 & 5.10 & 0.028 & 13.23 & 0.075 \\
5 & BCL & 4.764 & 0.029 & 8.90 & 0.098 \\
\hline
\end{tabular}

Table 8. Difference in assay values

Assay of BCL (\% w/w)

\begin{tabular}{ccc}
\hline Sample & Unspiked sample & Spiked sample \\
\hline 1 & 99.70 & 99.81 \\
2 & 99.55 & 100.13 \\
3 & 99.76 & 99.61 \\
Mean & 99.67 & 99.85 \\
SD & 0.11 & 0.26 \\
RSD (\%) & 0.11 & 0.26 \\
\hline
\end{tabular}




\section{Acknowledgement}

Through this section, we want to thanks Sun Pharmaceuticals, for providing gift samples of Bicalutamide.

\section{Conflict of Interest}

None declared

\section{References}

1. Sadeghi-Gandomani HR, Yousefi MS, Rahimi S, Yousefi SM, Karimi-Rozveh A, Hosseini S, Mahabadi AA, Abarqui HF, Borujeni NN, Salehiniya $H$. The incidence, risk factors, and knowledge about the prostate cancer through worldwide and Iran. World J Cancer Res. 2017; 4 (4): e972.

2. Hassanipour-Azgomi S, Mohammadian-Hafshejani A, Ghoncheh M, Towhidi F, Jamehshorani S, Salehiniya H. Incidence and mortality of prostate cancer and their relationship with the Human Development Index worldwide. Prostate Int. 2016 Sep;4(3):118-24. DOI: 10.1016/j.prnil.2016.07.001.

3. Shen HC, Balk SP. Development of androgen receptor antagonists with promising activity in castration-resistant prostate cancer. Cancer Cell. 2009 Jun 2;15(6):461-3. DOI: 10.1016/j. ccr.2009.05.005.

4. PubChem [Internet]. Bethesda (MD): National Library of Medicine (US), National Center for Biotechnology Information; 2004-. PubChem Compound Summary for CID 2375, Bicalutamide; [cited 2020 Oct. 30]. Available from: https://pubchem. ncbi.nlm.nih.gov/compound/Bicalutamide.

5. Eric S. Bicalutamide. xPharm: The Comprehensive Pharmacology Reference 2007, pp. 1-5. DOI: https://doi.org/10.1016/ B978-008055232-3.62975-7

6. Folake AO, Amy EM, McEwan IJ. Androgen Receptor Ligands: Agonists and Antagonists. Reference Module in $\mathrm{Bi}$ omedical Sciences. Encyclopedia of Reproduction (Second Edition). vol 1; 2018: 234-241.

7. Parihar JS, Kim IY. Second-Line Hormonal for Castrate-Resistant Prostate Cancer. Prostate Cancer (Second Edition). Science and Clinical Practice. 2016; 533-540.

8. Reddy VP. Organofluorine Compounds as Anticancer Agents. Organofluorine Compounds in Biology and Medicine. 2015; 265-300. DOI: https://doi.org/10.1016/B978-0-444-53748$5.00009-5$.

9. Piotrowski Z, Greenberg RE. Antiandrogen Monotherapy in the Treatment of Prostate Cancer. Prostate Cancer (Second Edition). Science and Clinical Practice. 2016, 515-521. DOI: https://doi.org/10.1016/B978-0-12-800077-9.00055-4.
10. Sancheti PP, Vyas VM, Shah M, Karekar P, Pore YV. Spectrophotometric estimation of Bicalutamide in tablets. Indian J Pharm Sci. 2008; 70(6): 810-812. DOI: 10.4103/0250474X.49131.

11. Balaram VM, Rao JV, Khan MMA, Sharma JVC, Sreedevi K. Visible spectrophotometric determination of Bicalutamide in bulk drug and pharmaceutical formulations. Int J Chem Sci.: 7(3), 2009, 1606-1612.

12. Smith A, Manavalan R, Kannan K, Rajendiran N. Spectrofluorimetric Determination of Bicalutamide in Formulation and Biological Fluids. Asian J Chem. 21(1);2009: 459-466.

13. Ventura E, Gadaj A, Monteith G, Ripoche A, Healy J, Botrè F, Sterk S, Buckley T, Mooney MH. Development and validation of a semi-quantitative ultra-high performance liquid chromatography-tandem mass spectrometry method for screening of selective androgen receptor modulators in urine. J Chromatogr A, 2019;1600:183-196. DOI: https://doi.org/10.1016/j.chroma.2019.04.050

14. Suresh PS, Kumar SV, Kumar A, Mullangi R. Development of an LC-MS/MS method for determination of bicalutamide on dried blood spots: application to pharmacokinetic study in mice. Biomed. Chromatogr. 2015; 29: 254-260. DOI 10.1002/ bmc.3268.

15. Sadutto D, Ferretti R, Zanitti L, Casulli A, Cirilli R. Analytical and semipreparative high performance liquid chromatography enantio separation of bicalutamide and its chiral impurities on an immobilized polysaccharide-based chiral stationary phase. J Chromatogr A, 2016. DOI: http://dx.doi.org/doi:10.1016/j. chroma.2016.04.011

16. Ramarao NT, Vidyadhara S, Sasidhar RLC, Deepti B, Surendra Yadav R. Development and Validation of LC-MS/MS Method for the Quantification of Chiral Separated R-Bicalutamide in Human Plasma. Ame J Analy Chem, 2013; 4: 63-76. DOI: http://dx.doi.org/10.4236/ajac.2013.42009.

17. Ventura E, Gadaj A, Buckley T, Mooney MH. Development of a multi-residue high-throughput UHPLC-MS/MS method for routine monitoring of SARM compounds in equine and bovine blood. Drug Test Anal. 2020;12:1373-1379. DOI: 10.1002/ dta. 2875 .

18. Gadaj A, Ventura E, Ripoche A, Mooney MH. Monitoring of selective androgen receptor modulators in bovine muscle tissue by ultra-high performance liquid chromatography-tandem mass spectrometry. Food Chem X. 2019 ;4:100056. DOI: 10.1016/j.fochx.2019.100056.

19. Gomes FP, Garcia PL. Development and validation of a simple and sensitive high performance liquid chromatographic method for the simultaneous determination of anastrozole, bicalutamide, tamoxifen, and their synthetic impurities. Talanta. 2012;101:495-503. DOI: 10.1016/j.talanta.2012.10.004. 
20. Kim B, Hwa J, Seunghwan S, Lee LS, Yoon SH. Liquid Chromatography Tandem Mass Spectrometry Determination of Bicalutamide in Human Plasma and Application to a Bioequivalence Study. J Bioanal Biomed 3: 098-102. DOI:10.4172/1948593X.1000051.

21. Rao RN, Raju AN, Nagaraju D. An improved and validated LC method for resolution of bicalutamide enantiomers using amylose tris-(3,5-dimethylphenylcarbamate) as a chiral stationary phase. J Pharma Biomed Analy 2006;42: 347-353.

22. Rao R N, Narasa RA, Narsimha R. Isolation and characterization of process related impurities and degradation products of bicalutamide and development of RP-HPLC method for impurity profile study. J Pharm Biomed Anal. 2008;46(3):505-19.

23. Raman Nanduri VVSS, Prasad Adapa VSS, Kura RR. Development and Validation of Stability-Indicating HPLC and UPLC Methods for the Determination of Bicalutamide, J Chromatogr Sci, 2012;50(4): 316-323, DOI: https://doi. org/10.1093/chromsci/bms010.

24. Pandit UJ, Khan I, Wankar S, Raj KK, Limaye SN. Development of an electrochemical method for the determination of bicalutamide at the SWCNT/CPE in pharmaceutical preparations and human biological fluids. Anal Methods, 2015;7:1019210198. DOI: https://doi.org/10.1039/C5AY02025E.

25. Saravanan G, Rao BM, Ravikumar M, Suryanarayana MV, Someswararao N, Acharyulu PVR. A Stability-Indicating LC Assay Method for Bicalutamide. Chroma 2007;66: 219-222. DOI: https://doi.org/10.1365/s10337-007-0280-0.

26. Sharma K, Pawar GV, Giri S, Rajagopal S, Mullangi R. Development and validation of a highly sensitive LC-MS/MSESI method for the determination of bicalutamide in mouse plasma: application to a pharmacokinetic study. Biomed Chromatogr, 2012;26(12): 1589-95. DOI: https://doi.org/10.1002/ bmc. 2736 .

27. Singh AK, Chaurasiya A, Jain GK, Awasthi A, Asati D, Mishra G, Khar RK, Mukherjee R. High performance liquid chromatography method for the pharmacokinetic study of bicalutamide SMEDDS and suspension formulations after oral administration to rats. Talanta. 2009 Jun 15;78(4-5):1310-4. DOI: 10.1016/j.talanta.2009.01.058

28. Subramanian GS, Karthik A, Baliga A, Musmade P, Kini S. High-performance thin-layer chromatographic analysis of bicalutamide in bulk drug and liposomes. J Planar Chromatography. Modern TLC. 2009;22(4):273-276. DOI: https://doi. org/10.1556/JPC.22.2009.4.6.

29. Raghu K, Chandrasekar A, Sankaran KR. Electrochemical behavior and differential pulse voltametric determination of an antineoplastic drug bicalutamide and pharmaceuticals formulations using glassy carbon electrode. Inter J Chem Res, 2010;2:516. DOI: http://dx.doi.org/10.9735/0975-3699.2.2.5-16.
30. Hua-Bin L, Xiang-Rong X, Feng C. Determination of Iodine in Seawater: Methods and Applications. Comprehensive Handbook of Iodine Nutritional, Biochemical, Pathological and Therapeutic Aspects. 2009, Pages 2-13.

31. M. Sargent (Ed.), Guide to achieving reliable quantitative LC-MS measurements, RSC Analytical Methods Committee, 2013. ISBN 978-0-948926-27-3.

32. Boers J, Venema CM, de Vries EFJ, Hospers GAP, Boersma HH, Rikhof B, Dorbritz C, Glaudemans AWJM, Schröder CP. Serial $\left[{ }^{18} \mathrm{~F}\right]$-FDHT-PET to predict bicalutamide efficacy in patients with androgen receptor positive metastatic breast cancer. Eur J Cancer. 2021 Feb;144:151-161. doi: 10.1016/j. ejca.2020.11.008.

33. Kandil SB, McGuigan C, Westwell AD. Synthesis and Biological Evaluation of Bicalutamide Analogues for the Potential Treatment of Prostate Cancer. Molecules. 2020 Dec 24;26(1):56. doi: 10.3390/molecules26010056.

34. Boers J, Venema CM, de Vries EFJ, Hospers GAP, Boersma HH, Rikhof B, Dorbritz C, Glaudemans AWJM, Schröder CP. Serial $\left[{ }^{18} \mathrm{~F}\right]$-FDHT-PET to predict bicalutamide efficacy in patients with androgen receptor positive metastatic breast cancer. Eur J Cancer. 2021 Feb;144:151-161. doi: 10.1016/j. ejca.2020.11.008

35. Malinowski B, Wiciński M, Musiała N, Osowska I, Szostak M. Previous, Current, and Future Pharmacotherapy and Diagnosis of Prostate Cancer-A Comprehensive Review. Diagnostics (Basel). 2019 Oct 25;9(4):161. doi: 10.3390/diagnostics 9040161 